\title{
Inhibition of HIV-1 infection by aqueous extracts of Prunella vulgaris $\mathrm{L}$.
}

\author{
ChoonSeok Oh ${ }^{1}$, Jason Price ${ }^{1}$, Melinda A Brindley ${ }^{1,4}$, Mark P Widrlechner ${ }^{2}$, Luping Qu², Joe-Ann McCoy ${ }^{2,5}$, \\ Patricia Murphy ${ }^{3}$, Cathy Hauck ${ }^{3}$ and Wendy Maury ${ }^{1 *}$
}

\begin{abstract}
Background: The mint family (Lamiaceae) produces a wide variety of constituents with medicinal properties. Several family members have been reported to have antiviral activity, including lemon balm (Melissa officinalis L.), sage (Salvia spp.), peppermint (Mentha $\times$ piperita L.), hyssop (Hyssopus officinalis L.), basil (Ocimum spp.) and selfheal (Prunella vulgaris L.). To further characterize the anti-lentiviral activities of Prunella vulgaris, water and ethanol extracts were tested for their ability to inhibit HIV-1 infection.

Results: Aqueous extracts contained more anti-viral activity than did ethanol extracts, displaying potent antiviral activity against HIV-1 at sub $\mu \mathrm{g} / \mathrm{mL}$ concentrations with little to no cellular cytotoxicity at concentrations more than 100-fold higher. Time-of-addition studies demonstrated that aqueous extracts were effective when added during the first five hours following initiation of infection, suggesting that the botanical constituents were targeting entry events. Further analysis revealed that extracts inhibited both virus/cell interactions and post-binding events. While only $40 \%$ inhibition was maximally achieved in our virus/cell interaction studies, extract effectively blocked post-binding events at concentrations similar to those that blocked infection, suggesting that it was targeting of these latter steps that was most important for mediating inhibition of virus infectivity.

Conclusions: We demonstrate that aqueous P. vulgaris extracts inhibited HIV-1 infectivity. Our studies suggest that inhibition occurs primarily by interference of early, post-virion binding events. The ability of aqueous extracts to inhibit early events within the HIV life cycle suggests that these extracts, or purified constituents responsible for the antiviral activity, are promising microbicides and/or antivirals against HIV-1.
\end{abstract}

Keywords: human immunodeficiency virus HIV, antiviral, microbicide, plant extract, self-heal

\section{Background}

Prunella vulgaris, commonly known as "self-heal" or "heal-all", is a low-growing perennial herb with worldwide distribution. It is a member of the mint family Lamiaceae that has been used to treat wounds, inflammation, and other minor body disorders across multiple traditional cultures [1-4].

Bioactive compounds are plentiful in both aqueous and ethanol $P$. vulgaris extracts. Aqueous extracts contain abundant polyphenols and complex carbohydrates, whereas more hydrophobic metabolites, such as triterpenes and flavonoids along with some polysaccharides and polyphenols, are found in ethanol extracts [5-7].

\footnotetext{
* Correspondence: wendy-maury@uiowa.edu

'Department of Microbiology, University of lowa, lowa City, IA 52242, USA

Full list of author information is available at the end of the article
}

Prunella vulgaris polysaccharides have pro-inflammatory activities in a macrophage cell line [8] and immunomodulatory activity in other tumor lines [9], whereas several of its triterpenes contain significant antiinflammatory activity [10]. Large quantities of antioxidants are known to be present in aqueous $P$. vulgaris extracts with the polyphenolic compound, rosmarinic acid, being one of the most abundant [6,11].

$P$. vulgaris extracts are reported to have antiviral and anti-bacterial properties, although constituents responsible for these activities are incompletely characterized to date $[6,12,13]$. Anionic polysaccharides in aqueous extracts of $P$. vulgaris can decrease the replication of herpes simplex virus-1 and -2 (HSV-1, HSV-2) by preventing virus binding to cells [12,14-16].

\section{Biomed Central}

() 2011 Oh et al; licensee BioMed Central Ltd. This is an Open Access article distributed under the terms of the Creative Commons Attribution License (http://creativecommons.org/licenses/by/2.0), which permits unrestricted use, distribution, and reproduction in any medium, provided the original work is properly cited. 
Extracts have also been shown to contain activity against the lentiviruses, HIV-1 and equine infectious anemia virus (EIAV). Our earlier studies investigating the ability of aqueous $P$. vulgaris extracts to inhibit EIAV indicated that both virus binding and early post-binding events were inhibited [17]. Previous studies have identified $P$. vulgaris extract inhibition of a number of steps within the HIV life cycle including: virus binding [18], fusion [19], reverse transcription [13], integration [20], and protease activity [21]. While these steps of the life cycle may be inhibited in vitro, identification of which step(s) are inhibited during HIV infection remain poorly elucidated. For instance, rosmarinic acid extracted from other botanicals has proven effective against HIV-1 integrase in an in vitro assay [5]; however, this polyphenol is not responsible for the anti-retroviral activities of $P$. vulgaris extracts [22-24]. Additional members of the Lamiaceae, such as peppermint (Mentha $\times$ piperita L.) and lemon balm (Melissa officinalis L.), are also known to have anti-viral activities, but specific constituents responsible for those activities remain unidentified $[7,14]$.

To date, isolation and identification of $P$. vulgaris compounds inhibiting HIV-1 is limited to a sulfated polysaccharide called Prunellin [5]. This constituent is likely the same water-soluble, $10 \mathrm{kDa}$ anionic constituent that was demonstrated to interfere with HIV-1 virion binding to permissive cells by blocking CD4 interactions [18].

In our studies, evaluation of water and ethanol extracts from several $P$. vulgaris accessions demonstrated better anti-HIV activity in aqueous extracts than in ethanol extracts, with $50 \%$ inhibition of HIV infectivity $\left(\mathrm{IC}_{50}\right)$ at about $0.8 \mu \mathrm{g} / \mathrm{mL}$ of aqueous extracts. Aqueous extracts from $P$. vulgaris Ames 27664 and 27748 were found to be about 35 times more potent against HIV-1 infectivity than against EIAV [17]. This extract inhibited early events in the HIV-1 life cycle. As others have reported [18], our findings also indicated that aqueous extracts blocked HIV-1 binding to permissive cells; however, this blockage was incomplete with a maximum of $\sim 40 \%$ inhibition at extract concentrations that were more than an order of magnitude higher than the $\mathrm{IC}_{50}$, suggesting that binding interference was not primarily responsible for the observed antiviral activity. Instead, we found that post-binding entry events were strongly inhibited with an $\mathrm{IC}_{50}$ of about $1 \mu \mathrm{g} / \mathrm{mL}$, a value similar to that found when extract was added at the initiation of infection. Thus, we propose that inhibition of postbinding entry events accounts for the preponderance of the antiviral activity of $P$. vulgaris against HIV-1.

\section{Materials and methods}

\section{Growth and collection of $P$. vulgaris accessions}

All $P$. vulgaris plant samples were provided by the North Central Regional Plant Introduction Station
(NCRPIS, Ames, IA) of the U.S. Department of Agriculture - Agricultural Research Service. Accessions utilized in experiments were produced in Ames, IA and grown from seeds of populations collected in the U.S.A. and South Ossetia, Republic of Georgia. Accession details are provided in Table 1. Both seed and voucher specimens were collected from natural populations, and specimens were keyed to species $[25,26]$. Seeds from accessions were germinated in Petri plates at $25^{\circ} \mathrm{C}$, transferred to flats in a greenhouse $\left(20-25^{\circ} \mathrm{C}\right)$ before final field transfer into individual control pollinated screened cages in Ames, IA. Upper flowering portions of 14-month-old plants were harvested, dried for 1 week at $38^{\circ} \mathrm{C}$ in a forced-air dryer with constant humidity and ground for analysis. Dried samples were stored in sealed plastic bags overlayed with nitrogen gas at $-20^{\circ} \mathrm{C}$ until use. All voucher specimens representing both original and regenerated populations are stored in the Ada Hayden Herbarium, Iowa State University (Ames, IA: ISC). Seeds representing both original and regenerated populations are stored at the NCRPIS under controlled conditions $\left(-20^{\circ} \mathrm{C} ; 4^{\circ} \mathrm{C}\right.$ for regenerated samples). Information about the specific provenance of all accessions used for the experiments is available via the Germplasm Resources Information Network database at http://www.ars-grin.gov/npgs/acc/acc_queries.html.

\section{Extraction and fractionation of $P$. vulgaris}

All glassware was heated at $200^{\circ} \mathrm{C}$ for 2 hours to destroy endotoxin [27].

\section{Water extraction}

Boiling, endotoxin-free water was poured over dried $P$. vulgaris at a ratio of $100 \mathrm{~mL} / 6 \mathrm{~g}$ of dried tissue. The plant material was steeped, with constant stirring, for 1 hour and filtered through a G6 glass fiber circle (Fisher Scientific) in a Buchner funnel. The filtrate was centrifuged at $10,000 \times \mathrm{g}$ for 20 minutes to remove any additional particulates. The extract was lyophilized, weighed, and re-dissolved in either DMSO or sterile endotoxinfree water.

\section{Ethanol extraction}

Six g of dried P. vulgaris was extracted with $500 \mathrm{~mL}$ of $95 \%$ ethanol via Soxhlet for 6 hours. The extract was filtered, dried by rotary evaporation at $<40^{\circ} \mathrm{C}$ and then lyophilized. Extracts were resuspended in DMSO.

\section{Endotoxin levels of extracts and fractions}

All extracts and fractions were evaluated for endotoxin by using the Chromogenic Limulus Amebocyte Lysate Test kit per manufacturer's instructions (Cambrex Bioscience Inc.). This assay is able to detect concentrations of endotoxin of $\geq 0.07 \mathrm{EU} / \mathrm{mL}$. All extracts had $<0.07 \mathrm{EU} / \mathrm{mL}$ at the highest concentrations used in these studies. 
Table 1 Provenance of $\boldsymbol{P}$. vulgaris accessions used in this study

\begin{tabular}{ccc}
\hline Accession & Geographic Origin & Habitat \\
\hline Ames 27664 & North Carolina, USA & Lakeside along pine-oak forest \\
\hline Ames 27665 & North Carolina, USA & Roadside in spruce-fir forest \\
\hline Ames 27666 & North Carolina, USA & Trailside, rich mesic cove forest \\
\hline Ames 27748 & Missouri, USA & Roadside along prairie remnant, partly mowed \\
\hline Ames 28312 & lowa, USA & Muddy, rocky bed of Rock Creek \\
\hline Ames 28355 & lowa, USA & Des Moines River floodplain \\
\hline Ames 28356 & lowa, USA & Slump below sandstone cliff \\
\hline Ames 28358 & lowa, USA & Cleared woods \\
\hline Ames 28359 & lowa, USA & Springs in dense forest \\
\hline Ames 28313 & lowa, USA & Mesic prairie \\
\hline Ames 29161 & S. Ossetia, Republic of Georgia & Pine-spruce forest edge \\
\hline Ames 29156 & S. Ossetia, Republic of Georgia & Roadside along Tana River \\
\hline Ames 29160 & S. Ossetia, Republic of Georgia & Alpine meadow \\
\hline Ames 29155 & S. Ossetia, Republic of Georgia & Roadside along secondary subalpine meadow \\
\hline Pl 656839 & lowa, USA & Native prairie remnant \\
\hline Pl 656840 & lowa, USA & Shoreline of pond \\
\hline Pl 656841 & lowa, USA & Bottom ground field \\
\hline Pl 656842 & Missouri, USA & Roadside prairie remnant
\end{tabular}

\section{Cells and viral strains}

HeLa37 cells were maintained in high glucose DMEM with $10 \%$ fetal calf serum (FCS). These cells ectopically express CD4 and CCR5 and endogenously express CXCR4 [28]. All media were supplemented with penicillin and streptomycin.

Stocks of HIV-1 were generated by transient transfections of 293T cells. The molecular clones, pNL4-3 [29], pAd8 [30] or p256 [31], were transfected into $80 \%$ confluent $15 \mathrm{~cm}$ plates of $293 \mathrm{~T}$ cells using either a calcium phosphate protocol or a PEI lipofection protocol as described [32]. Supernatants were collected at 48 hours following transfection, filtered through a $0.45 \mu$ filter, distributed into $500 \mu \mathrm{L}$ aliquots and stored at $-80^{\circ} \mathrm{C}$. Viral titers were determined by infection of HeLa37 cells with the single round of infection assay as previously described [33].

\section{Viral infection and time-of-addition studies Inhibition of infectivity studies}

Approximately 200 infectious HIV-1 particles were combined with the concentrations of extracts as noted. The amount of vehicle was adjusted so that equivalent concentrations of vehicle were present in all wells within an experiment. In studies that used extracts resuspended in DMSO, DMSO concentrations never exceeded $0.5 \%$. The extract and virus mixture was added to $2 \times 10^{4}$ cells/well of HeLa37 cells in a 48-well format, resulting in a multiplicity of infection (MOI) of $\sim 0.01$. The cells were maintained for 40 hours. Cells were fixed with $75 \%$ acetone/25\% water and immunostained for HIV antigens, as previously described [33], with human anti-HIV antisera. HIV antigen-positive cells within the infected cell monolayer were counted and titers determined. $\mathrm{IC}_{50}$ and $\mathrm{IC}_{90}$ concentrations were determined with TableCurve software (Systat Academic).

To quantify the number of logs of virus infectivity inhibited by the extract, approximately $1.15 \times 10^{4}$ infectious particles of NL4-3 were incubated at room temperature for 10 minutes with various concentrations of P. vulgaris accession Ames 27748 aqueous extract. Following the incubation, serial dilutions of the incubated virus were added to $2 \times 10^{4} \mathrm{HeLa} 37$ cells in a 48-well format and appropriate concentrations of extract on the cells were maintained for the duration of the experiment. Cells were fixed at 40 hours following infection and immunostained as described above. Wells with serial dilutions containing between 10 and 250 virus positive cells were counted and back-calculations made to obtain the numbers of infectious units of virus $/ \mathrm{mL}$.

\section{Virion-stability studies}

Sucrose step gradients were prepared by layering $250 \mu \mathrm{L}$ aliquots of decreasing concentrations of sucrose (20\%$60 \%$ ) into $3 \mathrm{~mL}$ ultra centrifugation tubes. The gradients were allowed to equilibrate at $4^{\circ} \mathrm{C}$ for 3 hours. Virions were treated with $132 \mu \mathrm{g} / \mathrm{mL}$ of aqueous Ames 27664 extract or $126 \mu \mathrm{g} / \mathrm{mL}$ of aqueous Ames 27748 extract, $0.5 \%$ Triton-X 100 or $0.4 \%$ DMSO for 1 hour at $37^{\circ} \mathrm{C}$ and loaded onto the top of the gradients. Tubes were centrifuged for 16 hours at 40,000 rpm in a SW60 rotor 
at $4{ }^{\circ} \mathrm{C}$ and stopped without a brake. Two hundred and fifty $\mu \mathrm{L}$ aliquots were collected beginning from the top of the tube and stored at $-80^{\circ} \mathrm{C}$ until analyzed by immunoblotting.

\section{Time of addition studies}

Approximately 200 infectious particles of NL4-3 were added to wells containing $2 \times 10^{4} \mathrm{HeLa} 37$ cells $(\mathrm{MOI}=$ 0.01). Extracts of P. vulgaris Ames $27748(10 \mu \mathrm{g} / \mathrm{mL})$ or vehicle were added to triplicate wells every hour beginning at 2 hours prior to infection and continuing until 8 hours after initiation of infection. Forty hours following infection, the cells were fixed, immunostained for HIV antigens, and the HIV-1 positive cells counted.

\section{Extract/cell pre-incubation studies}

Extract $(0.1$ to $50 \mu \mathrm{g} / \mathrm{mL})$ was incubated in growth media at $37^{\circ} \mathrm{C}$ with $2 \times 10^{4}$ cells/well of HeLa37 cells in a 48-well format for 1 hour. At the end of the incubation, media containing the extract was removed, the cells were washed in $1 \times$ PBS twice, and refreshed with growth media. Approximately 250 infectious HIV-1 particles were added to the treated cells resulting in a MOI of 0.012. Cells were fixed at 40 hours following infection and immunostained as described above.

\section{Extract/virion pre-incubation studies}

Approximately $4 \times 10^{4}$ infectious HIV-1 particles were combined with extracts $(0.3$ to $30 \mu \mathrm{g} / \mathrm{mL})$ and incubated at room temperature for 10 minutes. The mixture was diluted 100 fold with media to reduce extract concentrations to irrelevant levels and added to $2 \times 10^{4}$ cells/well of HeLa37 cells in a 48-well format, resulting in a final MOI of 0.02. Cells were fixed at 40 hours following infection and immunostained as described above.

\section{Binding studies}

HIV-1 NL4-3 (3.8 $\times 10^{5}$ infectious particles) was incubated with $2 \times 10^{4} \mathrm{HeLa} 37$ cells at $4^{\circ} \mathrm{C}$ for 1 hour (MOI $=19$ ) in the presence of growth media (DMEM with $10 \%$ FCS) and increasing extract concentrations. This incubation step permitted virus/cell binding, but prevented virion internalization. Unbound virus was removed by washing the cells several times with growth media, and washed cells were then lysed with 1\% SDS. The cell lysates were separated on a 4-20\% SDS PAGE and proteins transferred to PVDF membrane. Membranes were probed for HIV capsid (rabbit antibody to p24; \#4250 NIH AIDS \& Reference Reagent Program) and HRP-conjugated mouse anti-human $\beta$-actin monoclonal antibody (Abcam, Cambridge, MA).

\section{Post-binding inhibition studies}

HIV-1 NL4-3 $\left(2 \times 10^{5}\right.$ particles $)$ was bound to $2 \times 10^{4}$ HeLa37 cells $(\mathrm{MOI}=10)$ at $4^{\circ} \mathrm{C}$ for 2 hour in DMEM with $10 \%$ FCS to permit binding, but prevent virion internalization. Media and unbound virus were removed, and cells were refreshed with growth media containing increasing extract concentrations and shifted to $37^{\circ} \mathrm{C}$.
Forty hours following infection, the cells were fixed, immunostained for HIV antigens, and HIV-positive cells counted.

\section{Cell-viability studies}

Cells were plated and treated with extracts as described above. Forty hours following treatment, cell viability was monitored by ATPLite Assay (Packard Biosciences) per manufacturer's instructions.

\section{Statistical analysis}

Studies were performed at least three independent times, except where noted in the figure legends. Means and standard errors of the mean are shown. Student's ttest was used to evaluate the statistical differences between control and experimental treatments, utilizing two-tailed distribution. A significant difference was determined by a p-value of $<0.05$ and significance is identified in each figure. If the p-value was $>0.05$, the data were not considered statistically significantly different.

\section{Results \\ Prunella vulgaris aqueous extracts inhibit HIV infectivity without significant cell toxicity}

Water and ethanol extracts were prepared from four accessions of $P$. vulgaris. These extracts were screened for their ability to inhibit virus generated from the welldescribed, X4-tropic lab molecular clone of HIV-1, pNL4-3, in a single-round infection assay in HeLa37 cells. Extracts and virus were diluted in media and immediately incubated with cells. Forty hours following infection, the cells were fixed, immunostained for expression of HIV antigens, and antigen-positive cells enumerated to determine the level of viral infection (Figure 1A). Although both ethanol and water extracts demonstrated some inhibition, all four water extracts contained significantly more anti-viral activity than did their respective ethanol counterparts. At the concentrations tested, all extracts had little or no cytotoxicity.

Aqueous extracts from 14 additional accessions of $P$. vulgaris from the northern hemisphere were also assessed for anti-HIV-1 activity. All extracts abrogated virus infection at $50 \mu \mathrm{g} / \mathrm{mL}$ with little cytotoxicity (Figure $1 \mathrm{~B}$ ). At 1 to $10 \mu \mathrm{g} / \mathrm{mL}$, some extracts appeared to be somewhat more inhibitory than others, with HIV1 replication inhibited by 33 to $66 \%$ at $1 \mu \mathrm{g} / \mathrm{mL}$ of the different extracts. As aqueous extracts of Ames 27664 and 27748 displayed some of the strongest anti-viral effects, these extracts were used for further study.

These aqueous extracts were evaluated for their inhibition of not only X4-tropic HIV-1, such a NL4-3, but also for the R5-tropic strain, AD8, and the dual-tropic strain, 256 [29-31]. We found that the extracts effectively 


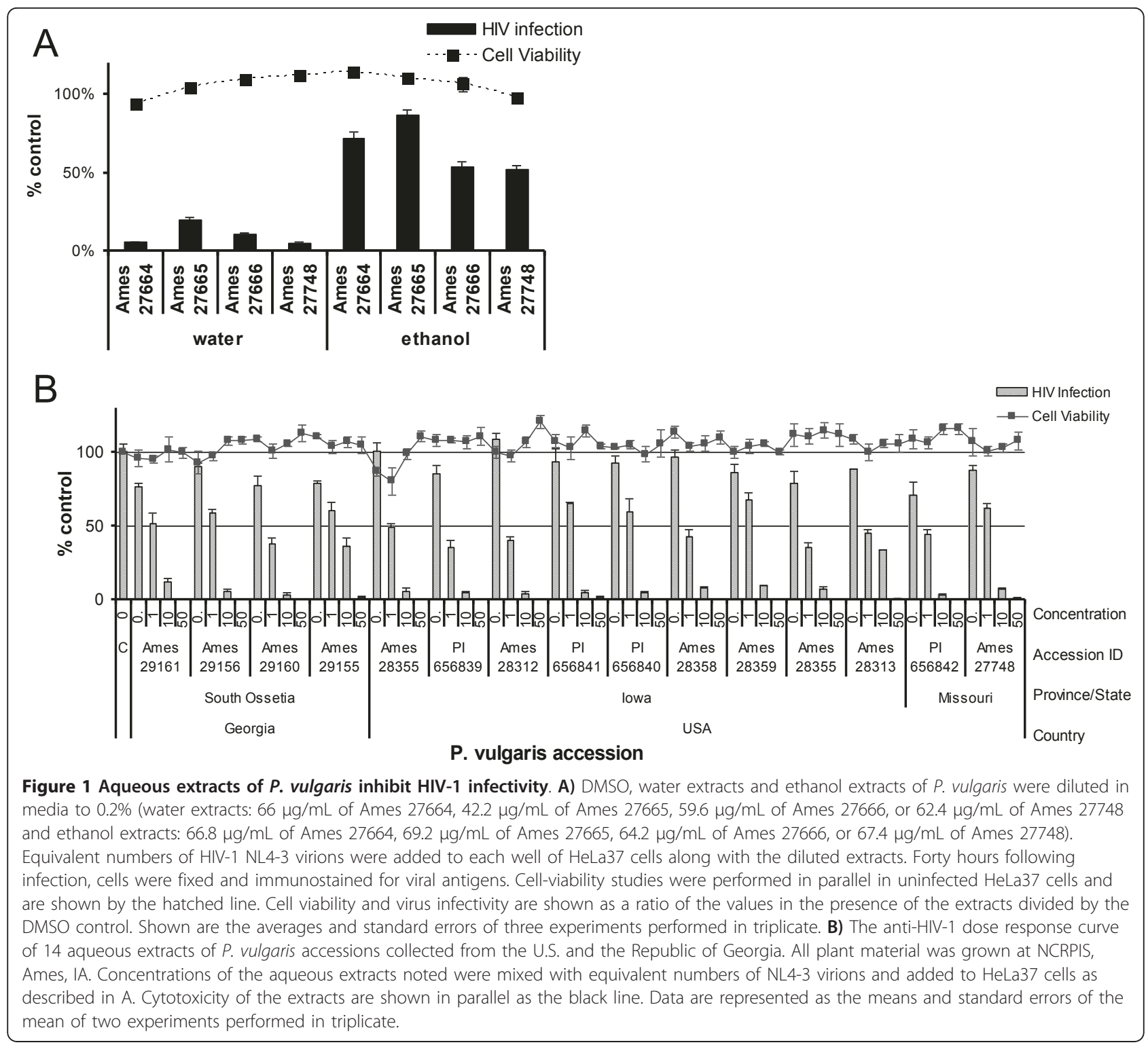

inhibited all three HIV-1 strains with similar concentrations inhibiting $50 \%$ of virus infectivity $\left(\mathrm{IC}_{50}=\sim 0.8 \mu \mathrm{g} /\right.$ $\mathrm{mL}$ ) (Figure 2A). Those concentrations that inhibited $90 \%$ of infectivity $\left(\mathrm{IC}_{90}\right.$ ) varied somewhat from about $3 \mu \mathrm{g} / \mathrm{mL}$ for NL4-3 and AD8 to $11 \mu \mathrm{g} / \mathrm{mL}$ for 256 . No extract cytotoxicity was observed at concentrations as high as $100 \mu \mathrm{g} /$ $\mathrm{mL}$, concentrations that completely abrogated virus infectivity. Accurate cytotoxicity curves and the generation of cytotoxicity concentration ${ }_{50}$ and 90 values $\left(\mathrm{CC}_{50}\right.$ and $\mathrm{CC}_{90}$ ) could not be obtained in these studies, since significant killing of the monolayer was not achieved. Consequently, we were unable to determine the selectivity index $\left(\mathrm{CC}_{50} / \mathrm{IC}_{50}\right)$ of $P$. vulgaris Ames 27748 aqueous extracts; however, our studies indicate a robust window between the two values.
To determine the logs of reduction in particle infectivity by $P$. vulgaris Ames 27748 extracts, we incubated $1.15 \times 10^{5}$ infectious virions of NL4-3 with 0.03 to 30 $\mu \mathrm{g} / \mathrm{mL}$ of aqueous extract. Virions were serially diluted in media maintaining appropriate concentrations of extract and added to HeLa37 cells. Virus infectivity was evaluated 40 hours later. Incubation of virions with aqueous extract reduced virion infectivity $\sim 140$-fold, an inhibition similar to that reported for a number of clinically relevant antivirals (Figure 2B) [34].

\section{Prunella vulgaris extracts inhibit early steps in the HIV-1 life cycle}

To identify the step(s) during the viral life cycle that are inhibited by the aqueous extracts, time-of-addition 


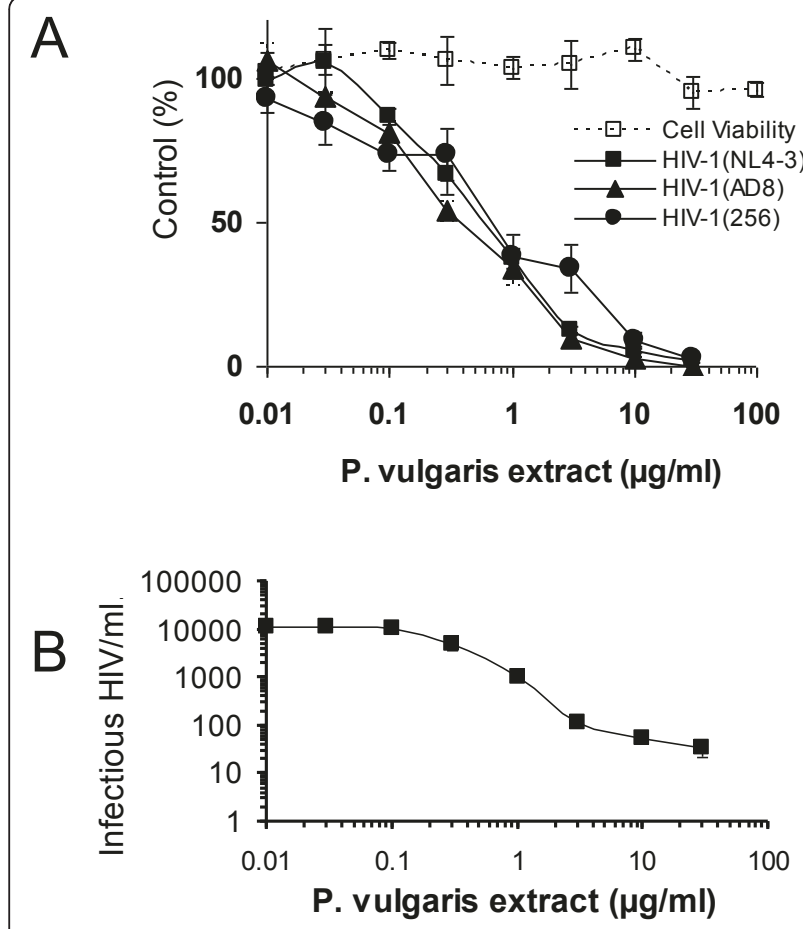

Figure 2 Aqueous $P$. vulgaris extracts inhibit both $\mathrm{X} 4$ and R5 HIV-1. A) Dose response curves of extract inhibition of $X 4$ virus NL4-3 (squares), R5 virus AD8 (triangles) and dual tropic 256 virus (circles). Cytotoxicity of extract was performed in parallel in uninfected cells (open squares). Infections were maintained for forty hours. Cells were fixed and immunostained for HIV antigens and number of HIV antigen-positive cells enumerated. Data are presented as the percent of control infections that did not have extract added. Shown are the averages and standard errors of three experiments performed in triplicate. B) Log-log plot of HIV-1 NL4-3 replication in the presence of aqueous $P$. vulgaris extract. Extract was incubated with $1.15 \times 10^{5}$ infectious virions and the mixture serially diluted in media containing appropriate amounts of extract and added to HeLa37 cells. Infected cells were maintained for 40 hours, fixed and immunostained for HIV antigens as described in A. Shown are the averages and standard errors of three experiments performed in triplicate.

experiments were performed. HeLa37 cells were infected with NL4-3 at time zero. At times noted in Figure 3, a final concentration of $10 \mu \mathrm{g} / \mathrm{mL}$ of aqueous $P$. vulgaris extract was added to each well, and the infection continued for a total of 40 hours. Addition of extracts at the initiation of infection resulted in $>95 \%$ inhibition of HIV-1 infection. Adding the extract one hour following initiation of infection reduced the inhibitory activity of the extract slightly to $87 \%$ inhibition and by 4 hours the extract was $<50 \%$ as effective as when it was added at the initiation of infection (Figure 3). Studies have shown that reverse transcription of the HIV-1 genome is initiated at $\sim 5$ hours following infection and requires several further hours for complete genomic DNA synthesis $[35,36]$. Thus, the extract must be inhibiting one or

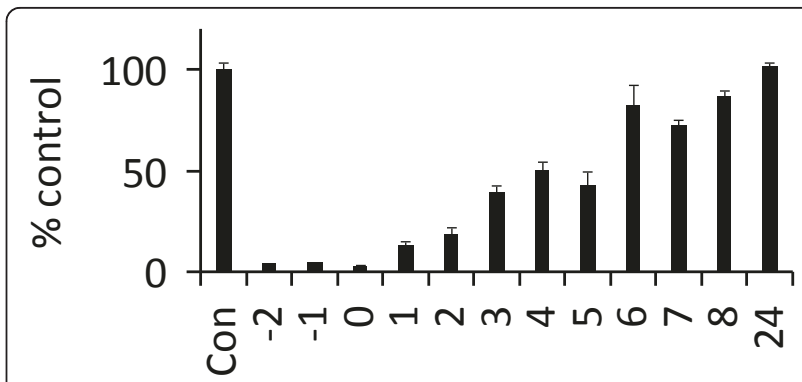

Hour of addition of extract

Figure 3 Time-of-addition studies. HIV-1 NL4-3 virions ( $\mathrm{MOI}=$ 0.01 ) were added to HeLa37 cells at time zero. A final concentration of $10 \mu \mathrm{g} / \mathrm{mL}$ of $P$. vulgaris Ames 27748 extract was added to the cultures at times noted and extract was maintained on the cells for the remainder of the infection. Cells were fixed and immunostained for viral antigens at 40 hours following initiation of the experiment. Data are represented as the percent of control wells (Con) that did not have extract added. Each experiment was performed in triplicate and independently performed three times. Shown are the mean and standard error of the mean for each time point.

more steps of the HIV-1 life cycle prior to reverse transcription.

To further dissect the mechanism of aqueous $P$. vulgaris extract inhibition, we assessed whether the extracts were altering the integrity of viral particles, thereby rendering them non-infectious. Previous studies with extracts from other Lamiaceae species demonstrated that botanical constituents alter the density of virions, suggesting that components of the extract were binding to the virus particles and perhaps inactivating them [7]. HIV-1 NL4-3 was incubated with a final concentration of $132 \mu \mathrm{g} / \mathrm{mL}$ of aqueous extract of Ames 27664 or 126 $\mu \mathrm{g} / \mathrm{mL}$ of Ames 27748 extract for one hour at $37^{\circ} \mathrm{C}$. As a control, $0.5 \%$ Triton $\mathrm{X}-100$ was added to virions to lyse the viral particles. Samples were separated on a discontinuous sucrose gradient by ultracentrifugation. Fractions were collected and analyzed for HIV-1 capsid p24 by immunoblotting, thereby assessing the location of a virion-associated HIV protein within the sucrose gradient. Capsid protein was present primarily in fractions 57 of untreated samples, whereas Triton X-100 shifted capsid nearer the top of the gradient, indicating lysis of the virions (Figure 4). The location of capsid remained in fractions 6 and 7 in the presence of high concentrations of either extract, demonstrating that virions remain intact in the presence of the extract. This finding also suggested that the extracts were not heavily coating the virions, thereby altering their density.

We performed three different assays to determine if $P$. vulgaris aqueous extracts altered virion/cell interactions. In our first set of studies, extracts were pre-incubated for 1 hour at $37^{\circ} \mathrm{C}$ with HeLa37 cells. Unbound extract was removed, media was refreshed, virus was 


\section{Sucrose Gradient Fractions 1234567891011

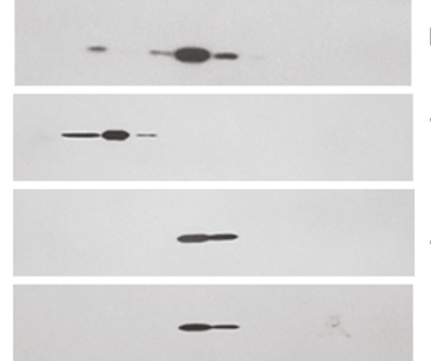 \\ Untreated virions \\ Triton X-100 \\ P. vulgaris Ames 27664 \\ P. vulgaris Ames 27748 \\ Ab: HIV p24 capsid \\ Figure 4 Density of HIV-1 is not altered by aqueous $P$. vulgaris extract. HIV NL4-3 virions were untreated or treated with $0.5 \%$ Triton $X-100,132 \mu \mathrm{g} / \mathrm{mL}$ of aqueous extracts of Ames 27664 or $126 \mu \mathrm{g} / \mathrm{mL}$ of Ames 27748 for 1 hour at $37^{\circ} \mathrm{C}$. Virus was applied to the top of a 20-60\% sucrose gradient and ultracentrifuged. Fractions were collected, separated on SDS PAGE and transferred to nitrocellulose. The blot was probed with an antibody against HIV-1 p24.}

added to the treated cells, and infections were assessed at 40 hours following initiation. Extract/cell pre-incubation had a small, but statistically significant inhibition of HIV infectivity, decreasing infection by about $20 \%$ at 10 to 100 $\mu \mathrm{g} / \mathrm{mL}$ of extract (Figure $5 \mathrm{~A}$ ). We also assessed if the preincubation of extracts with virions affected virus infectivity. When virus was pre-incubated with extract and the mixture was diluted with media 100 fold to achieve irrelevant concentrations of extract prior to addition to cells, partial inhibition of infectivity was achieved with as little as $1 \mu \mathrm{g} / \mathrm{mL}$ and as high as $30 \mu \mathrm{g} / \mathrm{mL}$, providing evidence that extract and virions interact and this interaction provides partial inhibition of infectivity (Figure 5B). We also directly evaluated if the extract interfered with HIV binding to permissive cells. HIV-1 NL4-3 $(\mathrm{MOI}=2)$ was incubated with HeLa37 cells at $4^{\circ} \mathrm{C}$ for 2 hours in the presence of increasing concentrations of aqueous extract from $P$. vulgaris Ames 27748. Unbound viruses were removed with several washes, and cells were lysed. Cell lysates were
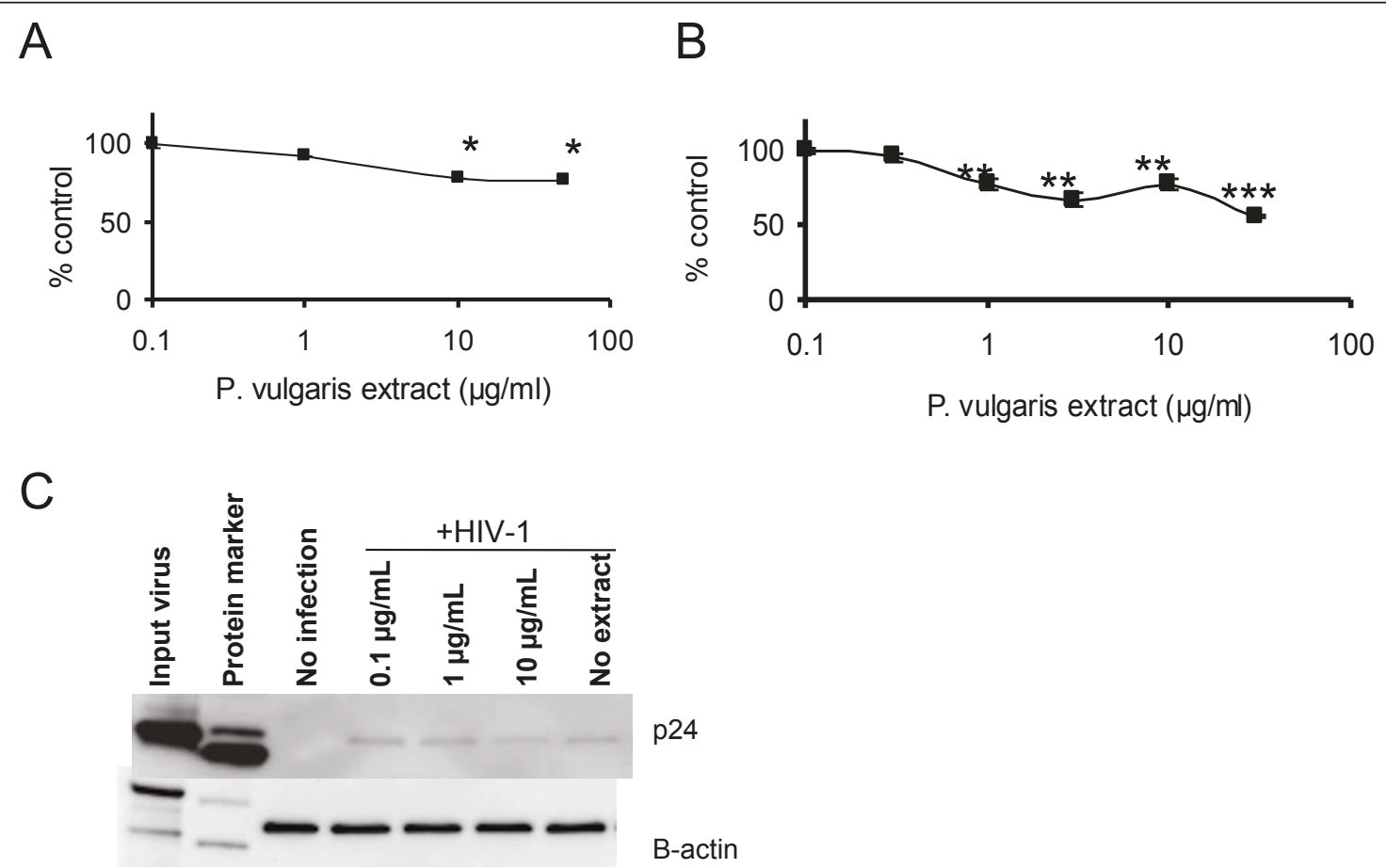

Figure 5 P. vulgaris extracts have a modest effect on HIV-1 binding to permissive cells. A) Pre-incubation of extract with cells. HeLa37 cells were pre-incubated with concentrations of aqueous extracts noted in the panel in DMEM with $10 \% \mathrm{FCS}$ for 1 hour at $37^{\circ} \mathrm{C}$. Unbound extracts were removed and cells were suspended in fresh media and 200 infectious units of HIV-1 NL4-3 added to the culture (MOI = 0.01). Cells were fixed and immunostained for HIV antigens 40 hours after infection. Pre-exposure of cells to extract reduced the level of virus infectivity by $20 \%$, which was statistically significantly different from the control. ${ }^{*}, \mathrm{p}<0.05$. B) Pre-incubation of extracts with virions. Approximately $4 \times 10^{4}$ infectious HIV-1 NL4-3 particles were combined with extracts and incubated at room temperature for 10 minutes. The mixture was diluted 100 fold with media to reduce extract concentrations to irrelevant levels and added to $2 \times 10^{4}$ cells/well of HeLa37 cells in a 48-well format, resulting in a final $\mathrm{MOI}$ of 0.02 . Cells were fixed at 40 hours following infection and immunostained as described above. ${ }^{* *}, p<0.01 ;{ }^{* * *}, p<$ 0.001 . C) Ability of extracts to inhibit HIV-1 binding to cells. Increasing concentrations of P. vulgaris extract were incubated with HIV-1 NL4-3 (3.8 $\times 10^{5}$ infectious particles) $(\mathrm{MOI}=19)$ and $2 \times 10^{4}$ HeLa37 cells at $4^{\circ} \mathrm{C}$ for 2 hours in DMEM with $10 \% \mathrm{FCS}$. Unbound virus was removed with several washes of media and cells were then lysed. Cell lysates were immunoblotted for HIV-1 p24 and cellular $\beta$-actin. All experiments were performed in triplicate and independently performed three times. 
separated by SDS PAGE and transferred to nitrocellulose. Blots were probed for both capsid p 24 and $\beta$-actin. The presence of $10 \mu \mathrm{g} / \mathrm{mL}$ of extract modestly decreased virus binding to cells, consistent with the decrease in infectivity shown in Figure 5A and 5B (Figure 5C). In total these findings support the possibility that extract blocks HIV binding to cells as others have reported $[5,18]$. However, inhibition was incomplete even at extract concentrations that were significantly higher than those required to inhibit virus infectivity, suggesting that other steps within the virus life cycle are also inhibited by compounds in the extract.

To determine if entry events that are downstream from virus binding were inhibited by the extract, NL4-3 was incubated with HeLa37 cells at $4^{\circ} \mathrm{C}$ for 2 hours to allow virus binding, but prevent internalization. Unbound virus was washed away, prewarmed media containing increasing concentrations of extract were added to the cells, and the cells were then shifted to $37^{\circ} \mathrm{C}$ for the remainder of the experiment. In these experiments, the extract effectively inhibited HIV infectivity with a similar dose response curve and at a similar $\mathrm{IC}_{50}$ concentration to that found when extract was added at the initiation of infection (Figure 6). These findings supported the possibility that postbinding events are inhibited by the extract and that this inhibition is likely to be primarily responsible for the inhibition of HIV-1 infectivity by the P. vulgaris extract.

\section{Discussion}

This study explored the antiviral activity of $P$. vulgaris extracts against HIV-1. Aqueous extracts from several accessions demonstrated more robust antiviral activity

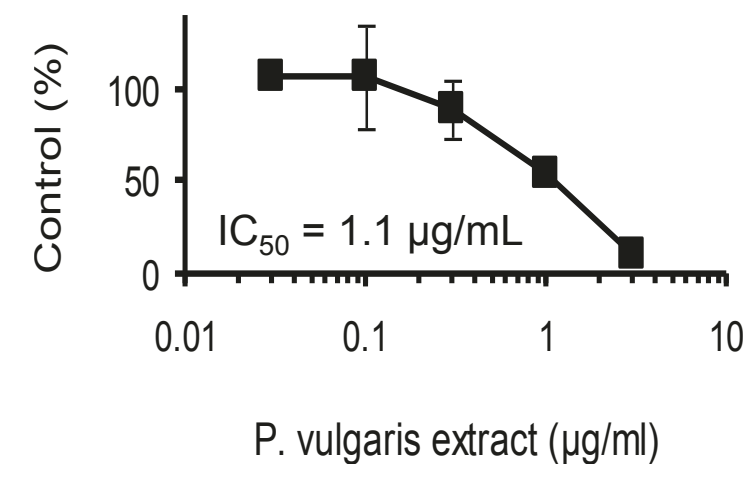

Figure 6 Aqueous $P$. vulgaris extracts inhibit early post-binding events in the HIV-1 life cycle. HIV-1 NL4-3 was bound to HeLa37 cells for 2 hours at $4^{\circ} \mathrm{C}$. Unbound virus was removed and the cells were refreshed with warmed media containing noted amounts of aqueous extract. Infections were maintained for an additional 40 hours, fixed and immunostained for HIV antigens. Data are represented as the percent of control wells that did not have extract added. Shown are the mean and standard error of the mean for each time point and studies were performed in triplicate three independent times. than did their ethanol counterparts, indicating that polar constituents are important for the antiviral activity. These findings are consistent with previous antiviral observations made with $P$. vulgaris extracts in studies against EIAV and HSV $[12,14,16,17]$. Time-of-addition studies demonstrated that early events within the life cycle of HIV-1 were inhibited. The extracts reduced virus infectivity by more than two logs and inhibited both R5and X4-tropic viruses, suggesting that inhibition was not occurring through interference with specific virion interactions with one of the host's chemokine receptors. The extracts were found to inhibit viral entry through at least two different mechanisms. Extracts interfered with HIV1 virion binding to permissive cells when pre-incubated with either virions or target cells; however, this inhibition was incomplete, maximally producing about $40 \%$ inhibition. Consistent with the relatively modest effect that the extract had in these experiments, HIV-1 binding to cells was only partially inhibited by high concentrations (10 $\mu \mathrm{g} / \mathrm{mL}$ or more) of extract. In contrast, the addition of extract following pre-binding of HIV-1 to cells was almost as effective at blocking virus infection as the addition of the extract at the time of infection. While we cannot exclude the possibility that the addition of extract is removing pre-bound viruses from the surface cells, our overall findings suggest that the extract principally inhibits HIV-1 infectivity by blocking one or more post-binding entry steps. An earlier study reported that aqueous $P$. vulgaris extracts interferes with six-helix bundle formation [19]. Our findings are consistent with these observations, suggesting that inhibition of virus fusion events may principally be responsible for the inhibition of HIV infectivity by $P$. vulgaris.

Interestingly, our studies with aqueous $P$. vulgaris extracts indicate that this extract has significantly stronger inhibitory activity against HIV-1 than against the related lentivirus EIAV, with HIV-1 inhibition observed with sub- $\mu \mathrm{g} / \mathrm{mL}$ concentrations of extracts. Using extracts from the same $P$. vulgaris accessions (Ames 27664 and 27748), EIAV inhibition occurred with an $\mathrm{IC}_{50}$ of $\sim 28 \mu \mathrm{g} / \mathrm{mL}$ [17]. As with HIV-1, aqueous extracts inhibited EIAV infection by blocking virus entry, impacting both binding and post-adherence events. Extract fractionation and identification of the bioactive constituents will be required to determine if a single compound, a related group of compounds or multiple, disparate ones are responsible for the anti-lentiviral effects and whether it is the same or different constituents responsible for inhibiting EIAV and HIV-1.

Identification and purification of the bioactive compounds that are present in the aqueous extracts of $P$. vulgaris is ongoing. Preliminary fractionation studies indicated that constituents with quite different solubility properties in ethanol have significant anti-HIV-1 
activity, suggesting that multiple antiviral compounds are present in the extract (data not shown). Our studies suggest that both large carbohydrates and tannins may contribute to the anti-HIV-1 activity. To date, a single anti-HIV constituent from $P$. vulgaris has been identified. This is a10 kDa sulfated carbohydrate called Prunellin that inhibits HIV entry [5]. Interestingly, a carbohydrate of approximately that same size was responsible for inhibiting HSV-1 entry into cells [16]. Prunellin may be responsible for the $P$. vulgaris inhibition of binding of these enveloped viruses to cells. Whether it is Prunellin or if other unidentified P. vulgaris constituents are responsible for the inhibition of post-binding entry events remains to be determined.

\section{List of abbreviations}

HIV: human immunodeficiency virus; EIAV: equine infectious anemia virus; HSV-1: herpes simplex virus-1; R5: CCR5 utilizing HIV; X4: CXCR4 utilizing HIV; DMSO: dimethyl sulfoxide

\section{Acknowledgements}

This publication was made possible by grant number 9P50AT004155-06 from the National Center for Complementary and Alternative Medicine (NCCAM) and Office of Dietary Supplements (ODS). Its contents are solely the responsibility of the authors and do not necessarily represent the official views of the NIEHS, NCCAM, or NIH. Mention of commercial brand names does not constitute an endorsement of any product by the U.S. Department of Agriculture or cooperating agencies.

\section{Author details}

${ }^{1}$ Department of Microbiology, University of lowa, lowa City, IA 52242, USA. ${ }^{2}$ U.S. Department of Agriculture-Agricultural Research Service, North Central Regional Plant Introduction Station, Ames, IA 50011, USA. ${ }^{3}$ Department of Food Science and Human Nutrition, lowa State University, Ames, IA 50011, USA. ${ }^{4}$ Department of Pediatrics, Emory University School of Medicine and Children's Healthcare of Atlanta, Atlanta, Georgia 303221, USA. ${ }^{5}$ Bent Creek Institute/NCSU, The North Carolina Arboretum, 100 Frederick Law Olmsted Way, Asheville, NC 28806, USA.

\section{Authors' contributions}

CSO and JP were responsible for all of studies performed and generated preliminary data figures. MB was responsible for oversight and direction of some studies. MPW, LQ and J-AM were responsible for obtaining and characterizing the Prunella vulgaris accessions. Furthermore, these individuals planted, maintained, harvested and processed the plant material. $\mathrm{CH}$ was responsible for the production of extracts and PM was responsible for the oversight of the production of all extracts. WM was responsible for oversight of the project including design and coordination of the study. In addition, she organized and wrote the manuscript and generated the final figures. All authors have read and approved of the final manuscript.

\section{Competing interests}

The authors declare that they have no competing interests.

Received: 16 November 2010 Accepted: 23 April 2011 Published: 23 April 2011

\section{References}

1. Chiej R: Encyclopaedia of Medicinal Plants MacDonald; 1984.

2. Hamada T: Studies on the medicinal plant in the "Sambutsu-cho" of Higo Province possessed by the Kumamoto clan (II): on the medicinal herbs. Yakushigaku Zasshi 1993, 28:63-72.

3. Mattioli PA: Kreuterbuch. Frankfurt am Main, Verlegung Sigmund Feyerabends, Peter Fischers, und Heinrich Dacken; 1586.
4. Pinkas $M$, Trotin F, Feng M, Torck M: Use, chemistry and pharmacology of the Chinese medicinal plants. Fitotherapia 1994, 55:343-353.

5. Tabba HD, Chang RS, Smith KM: Isolation, purification, and partial characterization of prunellin, an anti-HIV component from aqueous extracts of Prunella vulgaris. Antiviral Res 1989, 11:263-273.

6. Psotova J, Kolar M, Sousek J, Svagera Z, Vicar J, Ulrichova J: Biological activities of Prunella vulgaris extract. Phytother Res 2003, 17:1082-1087.

7. Geuenich S, Goffinet C, Venzke S, Nolkemper S, Baumann I, Plinkert P, Reichling J, Keppler OT: Aqueous extracts from peppermint, sage and lemon balm leaves display potent anti-HIV-1 activity by increasing the virion density. Retrovirology 2008, 5:27.

8. Fang X, Yu MM, Yuen WH, Zee SY, Chang RC: Immune modulatory effects of Prunella vulgaris L. on monocytes/macrophages. Int J Mol Med 2005, 16:1109-1116.

9. Fang $X$, Chang RC, Yuen WH, Zee SY: Immune modulatory effects of Prunella vulgaris L. Int J Mol Med 2005, 15:491-496.

10. Ryu SY, Oak MH, Yoon SK, Cho DI, Yoo GS, Kim TS, Kim KM: Anti-allergic and anti-inflammatory triterpenes from the herb of Prunella vulgaris. Planta Med 2000, 66:358-360.

11. Skottova N, Kazdova L, Oliyarnyk O, Vecera R, Sobolova L, Ulrichova J: Phenolics-rich extracts from Silybum marianum and Prunella vulgaris reduce a high-sucrose diet induced oxidative stress in hereditary hypertriglyceridemic rats. Pharmacol Res 2004, 50:123-130.

12. Chiu LC, Zhu W, Ooi VE: A polysaccharide fraction from medicinal herb Prunella vulgaris downregulates the expression of herpes simplex virus antigen in Vero cells. J Ethnopharmacol 2004, 93:63-68.

13. Kageyama S, Kurokawa M, Shiraki K: Extract of Prunella vulgaris spikes inhibits HIV replication at reverse transcription in vitro and can be absorbed from intestine in vivo. Antivir Chem Chemother 2000, 11:157-164.

14. Nolkemper S, Reichling J, Stintzing FC, Carle R, Schnitzler P: Antiviral effect of aqueous extracts from species of the Lamiaceae family against Herpes simplex virus type 1 and type 2 in vitro. Planta Med 2006, 72:1378-1382.

15. $\mathrm{Xu} \mathrm{HX}$, Lee $S H$, Lee SF, White RL, Blay J: Isolation and characterization of an anti-HSV polysaccharide from Prunella vulgaris. Antiviral Res 1999, 44:43-54.

16. Zhang Y, But PP, Ooi VE, Xu HX, Delaney GD, Lee SH, Lee SF: Chemical properties, mode of action, and in vivo anti-herpes activities of a lignincarbohydrate complex from Prunella vulgaris. Antiviral Res 2007, 75:242-249.

17. Brindley MA, Widrlechner MP, McCoy JA, Murphy P, Hauck C, Rizshsky L, Nikolau B, Maury W: Inhibition of lentivirus replication by aqueous extracts of Prunella vulgaris. Virol J 2009, 6:8.

18. Yao XJ, Wainberg MA, Parniak MA: Mechanism of inhibition of HIV-1 infection in vitro by purified extract of Prunella vulgaris. Virology 1992, 187:56-62.

19. Liu S, Jiang S, Wu Z, Lv L, Zhang J, Zhu Z, Wu S: Identification of inhibitors of the HIV-1 gp41 six-helix bundle formation from extracts of Chinese medicinal herbs Prunella vulgaris and Rhizoma cibotte. Life Sci 2002, 71:1779-1791.

20. Au T, Lam TL, Ng TB, Fong WP, Wan DC: A comparison of HIV-1 integrase inhibition by aqueous and methanol extracts of Chinese medicinal herbs. Life Sci 2001, 68:1687-1694

21. Lam TL, Lam ML, Au TK, Ip DT, Ng TB, Fong WP, Wan DC: A comparison of human immunodeficiency virus type- 1 protease inhibition activities by the aqueous and methanol extracts of Chinese medicinal herbs. Life Sci 2000, 67:2889-2896.

22. Kim HK, Lee HK, Shin CG, Huh H: HIV integrase inhibitory activity of Agastache rugosa. Arch Pharm Res 1999, 22:520-523.

23. Tewtrakul S, Miyashiro H, Nakamura N, Hattori M, Kawahata T, Otake T, Yoshinaga T, Fujiwara T, Supavita T, Yuenyongsawad S, et al: HIV-1 integrase inhibitory substances from Coleus parvifolius. Phytother Res 2003, 17:232-239.

24. Dubois M, Bailly F, Mbemba G, Mouscadet JF, Debyser Z, Witvrouw M, Cotelle $P$ : Reaction of rosmarinic acid with nitrite ions in acidic conditions: discovery of nitro- and dinitrorosmarinic acids as new antiHIV-1 agents. J Med Chem 2008, 51:2575-2579.

25. Weakley AS: Flora of the Carolinas, Virginia, and Georgia, and Surrounding Areas Chapel Hill, NC: University of North Carolina Herbarium (NCU), North Carolina Botanical Garden, University of North Carolina at Chapel Hill; 2007. 
26. Komarov VL, et al: Flora of the USSR. Moscow and Leningrad: Academy of Sciences of the USSR; 1934-1964;30.

27. Ludwig JD, Avis KE: Dry heat inactivation of endotoxin on the surface of glass. J Parenter Sci Technol 1990, 44:4-12.

28. Platt EJ, Wehrly K, Kuhmann SE, Chesebro B, Kabat D: Effects of CCR5 and CD4 cell surface concentrations on infections by macrophagetropic isolates of human immunodeficiency virus type 1. J Virol 1998, 72:2855-2864.

29. Adachi A, Gendelman HE, Koenig S, Folks T, Willey R, Rabson A, Martin MA: Production of acquired immunodeficiency syndrome-associated retrovirus in human and nonhuman cells transfected with an infectious molecular clone. J Virol 1986, 59:284-291.

30. Theodore TS, Englund G, Buckler-White A, Buckler CE, Martin MA, Peden KW: Construction and characterization of a stable full-length macrophage-tropic HIV type 1 molecular clone that directs the production of high titers of progeny virions. AIDS Res Hum Retroviruses 1996, 12:191-194.

31. Chesebro B, Wehrly K, Nishio J, Perryman S: Mapping of independent V3 envelope determinants of human immunodeficiency virus type 1 macrophage tropism and syncytium formation in lymphocytes. J Virol 1996, 70:9055-9059.

32. Reed SE, Staley EM, Mayginnes JP, Pintel DJ, Tullis GE: Transfection of mammalian cells using linear polyethylenimine is a simple and effective means of producing recombinant adeno-associated virus vectors. J Virol Methods 2006, 138:85-98.

33. Reed-Inderbitzin E, Maury W: Cellular specificity of HIV-1 replication can be controlled by LTR sequences. Virology 2003, 314:680-695.

34. Shen L, Rabi SA, Siliciano RF: A novel method for determining the inhibitory potential of anti-HIV drugs. Trends Pharmacol Sci 2009, 30:610-616.

35. Kim SY, Byrn R, Groopman J, Baltimore D: Temporal aspects of DNA and RNA synthesis during human immunodeficiency virus infection: evidence for differential gene expression. J Virol 1989, 63:3708-3713.

36. Donahue DA, Sloan RD, Kuhl BD, Bar-Magen T, Schader SM, Wainberg MA: Stage-dependent inhibition of HIV-1 replication by antiretroviral drugs in cell culture. Antimicrob Agents Chemother 2010, 54:1047-1054.

\section{Submit your next manuscript to BioMed Central and take full advantage of:}

- Convenient online submission

- Thorough peer review

- No space constraints or color figure charges

- Immediate publication on acceptance

- Inclusion in PubMed, CAS, Scopus and Google Scholar

- Research which is freely available for redistribution

Submit your manuscript at www.biomedcentral.com/submit
Ciomed Central 